\title{
THE TALENTS OF DONALD HOOPER
}

\begin{abstract}
C. STUART HOUSTON, 863 University Drive, Saskatoon, Saskatchewan. S7N $0 J 8$
\end{abstract}

On 28 April 1931, Donald Hooper and his twin brother Ron were born at the Red Cross Outpost Hospital, at what was then called Carragana (until the railroad came through in 1929), six miles north and two miles east of the present hamlet of Somme. This hospital, which operated from 1921 through 1948, served the Porcupine Soldier Settlement, Canada's largest soldier settlement, 200,000 acres withdrawn from the Porcupine Forest Reserve for returning soldiers after World War I. Donald died on 19 June 1993 in the successor to that hospital, the Porcupine-Carragana Union Hospital. His body is buried in the cemetery of St. Andrew's Anglican Church, immediately adjacent to the site of the former Red Cross Outpost Hospital.

At Donald Hooper's funeral, 22 June 1993, in the Somme Legion Hall, I gave the following eulogy, one of four presented on that occasion:

Donald Hooper was a man with unusual talents.

What do we mean by talent? About two thousand years ago in biblical times, a talent was a measure of weight - a weight of silver worth about 2,000 dollars or a weight of gold worth 25,000 dollars in 1950 . Perhaps worth ten times that much in 1993 dollars. A huge amount of money for the landowner to leave his servants to invest! From the "parable of the talents" in Matthew 25, beginning at verse 14, the word "talent" has come to mean a person with great ability and special aptitude. To quote from my Waverly Pictorial Dictionary, a talented person has a strength of intellect that can be trained to a pitch of excellence. Donald Hooper had talent. He was worth his weight in gold.

In 1 Corinthians 12, St. Paul lists some of the diverse talents that different people may be given. The first three listed are wisdom, knowledge and faith. Donald Hooper had all three. His faith and his intimate knowledge of the Bible sustained him through life. Although he had only a grade 8 school education, he became an educated man and a scholar in the true sense of the word, adding to his knowledge and acquiring wisdom. Prefacing a second statement about gifts in Romans 12, verse 2 , St. Paul says "Be ye transformed by the renewing of your mind." How appropriate! Donald continually renewed his mind, through observation and study. He had a sharp eye - not only did he see birds and plants and insects that others would have missed, his sharp eye fixed on Margaret Ashdown, his wonderful wife and lifelong partner, 


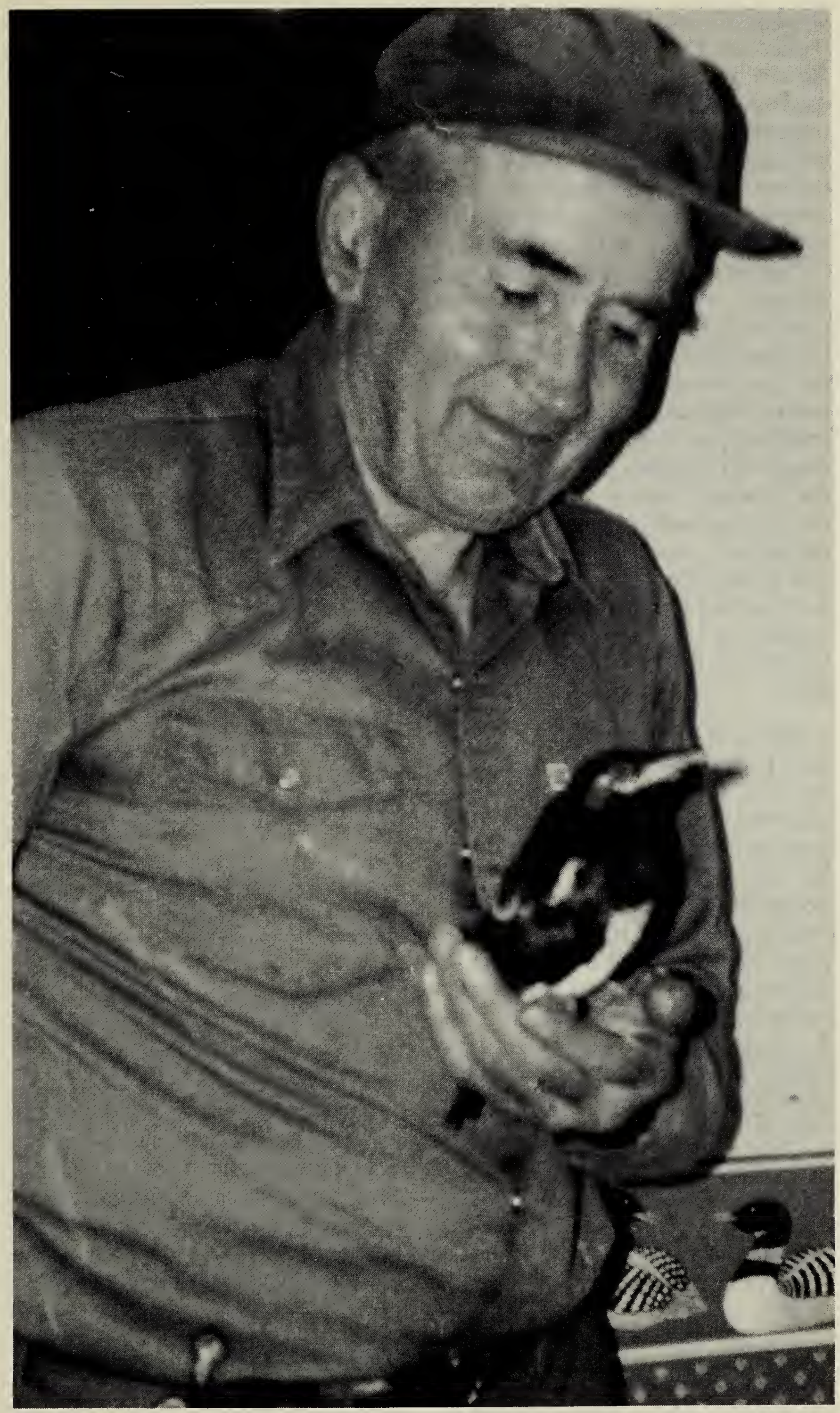

Don Hooper with a young magpie.

Margaret Hooper

51(3). September 1993 
who gave him unstinting support. He collaborated with his twin brother, Ronald, who shared his interest and worked with him regarding all phases of natural history. And his life was solidly based on his farm, producing food for the world. His feet were firmly rooted in the soil.

Donald was a man of integrity, strong, indefatigable, reflecting Psalm 25, verse 21: "Let integrity and uprightness preserve me." $\mathrm{He}$ met his one illness, a fatal brain tumour, with remarkable strength. In spite of his deteriorating physical state, with paralysis, in spite of radiation therapy which makes lesser men waste away, his mind remained remarkably clear almost until the end. Fellow birdwatcher Frank Roy marvelled at the good visit they had together on 20 May and I visited with Donald by telephone shortly thereafter.

Mary and I first visited the Hooper farm at Somme on 12 June 1953, to see the twin brothers' collection of mounted birds in a museum in a granary. Donald that day was working on a neighbouring farm, but Ronald and Edna showed us the impressive museum. But Don and Ron were in real trouble. They had stayed up late the night before, collecting moths in front of tractor lights. A wonderful collection was the happy result. Less happy was the other outcome: when their father went to start the tractor in the early morning to do his field work, its battery was dead. He had to pull the little tractor with horses to get it started. His enthusiasm for his sons' studies was temporarily dampened!

Donald Hooper was a man seldom seen since the 18th century, when gifted individuals might undertake to study all of God's creation. Rarely in our day do we see a well-rounded naturalist, knowledgeable about birds, plants, reptiles, insects. Let me mention just a few of his contributions to natural history. He contributed greatly to Ron's book, Butterflies of Saskatchewan, in 1973. He collected the third specimen of a beetle, known only from Medicine Hat and Edmonton in Alberta. He studied technical manuals of botany for adjacent areas, and searched specifically for species not yet found in Saskatchewan, adding thirteen plant species to the provincial list. His unfinished manuscript on the plant species of his area will be completed by his close field associate, Professor Vern Harms, of the Fraser Herbarium at the University. Donald found the first-ever nest of the Nashville Warbler in our province and followed enthusiastically the first nesting in over a century of Trumpeter Swans in Saskatchewan parkland. His articles in the Blue Jay were about reptiles and amphibians, as well as birds, mammals and plants. He and Ron wrote "A Preliminary List of the Birds of the Somme District, Saskatchewan" in 1954 and he finished his wonderful regional book, Birds of East-Central Saskatchewan, Kelvington to Kelsey Trail, in 1992. Not a bad record for a man with a country-school grade-8 education! I had the pleasure of delivering the first copies of his book to him in Royal University Hospital.

Donald was not only interested in science, he was deeply concerned with conservation: Wildcat Hill Provincial Wilderness Park, expanded on 24 August 1992; Rendek Elm Forest; Brockelbank Hill, south of Armit, designated as the Brockelbank Hill Protected Area on 24 August 1992; protection of the rare Rams'head Lady Slipper in Hudson Bay Regional Park. He was the Saskatchewan Natural History Society representative on the Saskatchewan 
Forestry Advisory Committee. He presented a brief concerning the rare and delicate plant species that need "cool moist woods to survive" and hence may be lost forever when forests are clear-cut. He founded the Hudson Bay Natural History Society. He wrote a nature column, illustrated with his own photographs, in the Hudson Bay Post-Review.

Donald Hooper was a talented man who, unlike many others, used his talents wisely all his life, for the benefit of his community and his province. He shared his talents. He maintained his boy-like enthusiasm and lived life to the full. He received a number of special honours. At the 1991 and 1992 annual meetings of the Saskatchewan Natural History Society, Donald received the Larry Morgotch Award for the best slide presentation, and in 1992 both he and his brother Ronald were named Fellows of the Society. He received the Canada 125 Commemorative Medal in 1993. At the Endangered Species Conference in February 1991, Donald received the Saskatchewan Award for his life-long work.

His accomplishments will live after him. We rejoice for the full life he lived.

On April nights when it has become warm enough to sit outdoors, we love to listen to the proceedings of the convention in the marsh. There are long periods of silence when one hears only the winnowing of snipe, the hoot of a distant owl, or the nasal clucking of some amorous coot. Then, of a sudden, a strident honk resounds, and in an instant pandemonium echoes. There is a beating of pinions on water, a rushing of dark prows propelled by churning paddles and a general shouting by the onlookers of a vehement controversy. Finally some deep honker has his last word, and the noise subsides to that half-audible small-talk that seldom ceases among geese. Once again, I wish I were a muskrat. Aldo Leopold. 1949. A Sand County almanac. Oxford. (Krutch and Eriksson. 1962. A treasury of birdlore. Eriksson, NY. P. 12) 